\title{
AN ECOSYSTEM SERVICES ANALYSIS OF OIL PALM AND ALTERNATIVE LAND USE SYSTEMS ON PEAT IN MALAYSIA
}

\section{JOLINE MIDDELBERG*; BADRUL AZHAR**; KHO LIP KHOON and PETER J VAN DER MEER ${ }^{\star}$}

\begin{abstract}
In this article, we assess the potential of alternative land use systems using non-drainage peatland species which could eventually phase out or partly replace oil palm plantations on undrainable peatlands. We have used the ecosystem services approach to analyse what scenarios using drainage-free peatland species could be suitable alternatives for oil palm cultivation on peat and how these scenarios compare to oil palm plantations in terms of selected ecosystem services. Our results indicate that alternative paludiculture systems will provide more direct and indirect ecosystem services than oil palm plantations on peat. We also found that stakeholders were aware of issues with growing oil palm on peat, and that there was a general intention for sustainable use of peatlands amongst several groups of stakeholders. Replacing oil palm with alternative systems such as paludiculture in Malaysia is not yet realistic. The most important impediments are a lack of knowledge on potential of non-drainage peatland species and its associated value chains, as well as the technical difficulty for smallholders to implement such a system. We recommend starting experimental plantings with paludiculture systems to further test species performance, life cycle analysis, growth, intercropping limitations and possibilities, yields and improvements in the value chain.
\end{abstract}

Keyword: oil palm, ecosystem services, paludiculture, peat, Malaysia.

Date received: 27 March 2019; Sent for revision: 18 April 2019; Received in final form: 25 July 2019; Accepted: 1 August 2019.

\section{INTRODUCTION}

The global demand for oil palm has increased rapidly over the last decade (World Growth, 2011; EPOA, 2016; Kushairi et al., 2017). At this moment 85\% of the oil palm plantations are found in Indonesia and Malaysia (EPOA, 2016). Currently, some 5.8

* Van Hall Larenstein University of Applied Sciences, Larensteinselaan 26-A, 6882 CT Velp,

Gelderland, The Netherlands.

E-mail: peter.vandermeer@hvhl.nl

** Biodiversity Unit, Institute of Bioscience, Universiti Putra Malaysia, 43400 UPM Serdang, Selangor, Malaysia.

‡ Malaysian Palm Oil Board, 6 Persiaran Institusi, Bandar Baru Bangi, 43000 Kajang,

Selangor, Malaysia. million hectares of land in Malaysia are covered by oil palm plantations, with an export revenue from oil palm reaching more than RM 46 billion in 2017 (MPOB, 2017; Kushairi et al., 2018). As suitable and accessible land has become scarce the cultivation has shifted from the more suitable mineral soils towards peatlands ${ }^{1}$ formerly covered by peat forest (Omar et al., 2010). These cultivations on peatlands have rapidly increased since the 1990s, mainly for oil palm and acacia plantations. By 2015, of the total peatland area in Malaysia, which is around 2.5 million hectares, approximately 1.06 million hectares were covered with oil palm plantations (Miettinen et al., 2016; Ishikura et al., 2018).

\footnotetext{
${ }^{1}$ The definition of peat used for this study is: 'tropical peat soils (Histosols) are organic soils with $65 \%$ or more organic matter and have a depth of $50 \mathrm{~cm}$ or more' (Lim et al., 2012).
} 
Growing oil palm on peat is complicated. Peatlands in Malaysia are originally predominantly covered by peat swamp forests (PSF). One of the most important characteristics of these peatlands is that they are waterlogged, which reduces the decomposition of organic matter, which then accumulates as peat. Therefore, before any cultivation can take place, the PSF needs to be cleared, leading to large losses of biodiversity and carbon stocks (Fitzherbert et al., 2008; Verwer et al., 2008; Posa et al., 2011). Secondly, as oil palms do not grow well in conditions with high ground water levels the peat needs to be drained to levels of 60$80 \mathrm{~cm}$ below soil surface (DID, 2001). With such a drainage depth the process of peat accumulation stops and the peat starts to decompose due to oxidation, resulting in large greenhouse gas (GHG) emissions (Verwer, et al., 2008; Hooijer et al., 2010). In addition, the drainage of peat will also lead to land subsidence (due to decomposition and shrinkage) which may result in flooding and eventually loss of plantable land, especially when combined with sea level rise caused by climate change (Hooijer et al., 2015; Page and Hooijer, 2016; Carlson and Garrett, 2018).

In response to the issues related to oil palm development on peat, the Roundtable on Sustainable Palm Oil (RSPO) has developed guidelines for sustainable management of existing oil palm plantations on peat as well as for the management and rehabilitation of vegetation surrounding oil palm plantations on peat (Lim et al., 2012). The RSPO recently revised the Principles and Criteria for RSPO certification, including a ban on new plantation developments on all peatlands (RSPO, 2018).

The challenge lies in finding economically viable and sustainable alternatives for oil palm on peat, which reduces the trade-off effect between economic and environmental benefits. An alternative system like paludiculture could provide a solution for this challenge (Giesen, 2013; FAO, 2014). Paludiculture (from Latin palus 'swamp and culture 'cultivation') is a wetland agricultural practice that produces biomass from wet and rewetted peatlands while maintaining the peatland's natural conditions (FAO, 2014; Wichtmann et al., 2016). Besides rewetting and contributing to peat soil conservation and the related carbon storage, paludiculture is promoted with timber, food and other by products or nontimber forest products (NTFP), that can provide economic returns (Widayati et al., 2016).

In order to assess the suitability of alternative scenarios with non-drainage peatland species, we use the ecosystem services ${ }^{2}$ approach which was used for the first time by the Millennium Ecosystem

\footnotetext{
${ }^{2}$ Ecosystem services can be defined as the benefit people obtain from ecosystems' and can be classified in four categories: provisioning, regulating, cultural and supporting services (Millennium Ecosystem Assessment, 2005).
}

Assessment (Millennium Ecosystem Assessment, 2005). It enables an unbiased quantification and valuation of various goods and services which the community (both local and global) receive from both natural and man-made ecosystems (FAO, 2014). We selected this widely used approach to compare whether and how these scenarios differ in some selected direct and indirect benefits we receive from these systems.

This study aimed to assess the opportunity for alternative paludiculture scenarios for peat areas in Malaysia that are currently cultivated with oil palm. We addressed this aim by trying to answer three research questions:

(1) Which non-drainage peatland species and what alternative management scenarios (as opposed to oil palm) could be used on rewetted peatlands?

(2) What are the costs and benefits of such alternative scenarios in terms of important ecosystems services?

(3) What are the perceptions on the peat issues and alternative scenarios amongst selected stakeholders in the oil palm sector?

\section{METHODS}

We used a combination of three methods to address the above research questions:

(1) A multi-criteria analysis of non-drainage peatland species as an alternative to oil palms.

(2) An analysis of ecosystem services provided by the four different peatland use scenarios.

(3) Interviews with stakeholders involved in the oil palm industry.

Multi-criteria Analysis for Selection of Nondrainage Peatland Species and Scenarios

Scenarios. Four scenarios were drawn up for this study which are illustrated in a conceptual drawing, Figure 1. The scenarios were assumed to start when the current oil palm cycle has come to an end, and they were drawn up for a time-frame of 30 years (based on the rotation length of oil palm which is around 25 years). The scenarios were derived and/ or adapted from reviews and case studies found in literature (Salleh and van den Berg, 2005; van der Meer and Ibie, 2009; Ismail et al., 2009; Sofiyuddin, 2012; Lim et al., 2012; Giesen, 2013; 2015; FAO, 2014; OAF, 2014; MPS, 2016; SIIA, 2017; Graham et al., 2017; Lampela et al., 2017). Differentiating factors like polyculture versus monoculture, and immediate change versus transitioning to a paludiculture system were taken into account when formulating the scenarios. No differentiation was made between the different oil palm ownership 


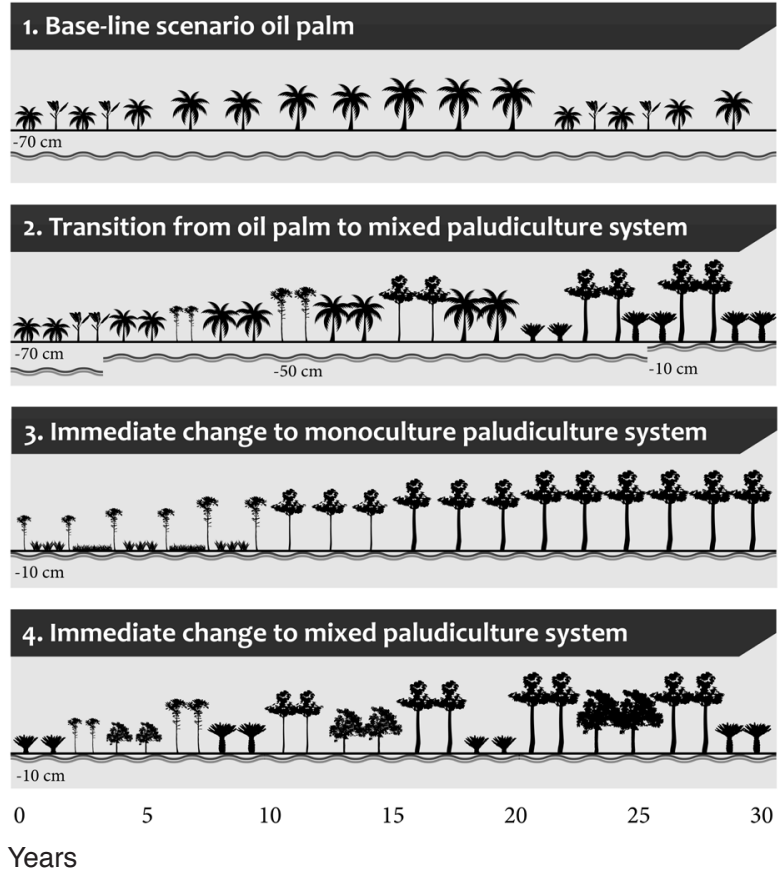

Figure 1. Conceptual drawing of the four scenarios. Scenario 1 illustrates the monoculture oil palm cultivation with an average drainage level of $-70 \mathrm{~cm}$. Scenario 2 illustrates the transition from a double avenue oil palm towards a mixed paludiculture system, including the transition of the drainage level from -70 to $-10 \mathrm{~cm}$. Scenario 3 illustrates a monoculture paludiculture system, and scenario 4 illustrates a mixed paludiculture system, both with an immediate drainage level transition towards $-10 \mathrm{~cm}$.

systems (i.e. smallholders and private estates). The first scenario, the base-line scenario, assumes another cycle with oil palm. Oil palm seedlings will be planted and intercropped with annual crops like banana, pineapple and yam for the first three years to receive yield and income before oil palms become productive. After three years oil palm will start to provide yield and the plantation will shift towards monoculture oil palm. Drainage levels are assumed to be $70 \mathrm{~cm}$ below surface. The second scenario is a transition from oil palm plantation towards a mixed paludiculture system. The palms will be planted in a double-row avenue planting system, where two rows of oil palm will be planted more closely together, with additionally more distance between the two rows of palms (Ismail et al., 2009). The oil palm should be intercropped with an annual species to produce additional income for the first three years (until oil palm becomes economically productive). By this time, drainage levels of the peat will go up from $70 \mathrm{~cm}$ to $50 \mathrm{~cm}$ depth. When the oil palm is mature enough, another species should be grown as an intercrop with oil palm to provide more income in the long-term. This species should be more suitable to undrained peat, preferably indigenous and has tolerances to flooding. When oil palm production declines after approximately 25 years, the palms can be replaced with other species, economically competitive to oil palm, though more suitable for undrained peat. At this stage, canal blocking can take place to provide suitable conditions for the non-drainage peatland species. Scenario 3 assumes a direct complete change from oil palm towards a monoculture paludiculture system by planting a fast growing cash crop that can compete with oil palm, though is more suitable for cultivation on wet peat soils. Canal blocking is in place as the first step of this management option to realise a ground water level (GWL) near the soil surface. Annual cash crops can be planted to provide income for the early years, until the initial crop starts producing. Scenario 4 assumes an immediate change to a mixed paludiculture system with 3-5 species. The water management should be improved by canal blocking to realise a GWL near the soil surface. The species should be a mixture of pioneer and climax species, appropriate for undrained peat, preferably tolerant to flooding, and provide economic benefit.

Species selection. A multi-criteria analysis was carried out to select suitable non-drainage peatland species. For the analysis, we selected species based on other recommended species lists for peat in South-east Asia. The following criteria were used for the final selection: species tolerances, suitability for paludiculture, commercial value, and species recommended for community trials in South-east Asia (Salleh and van den Berg, 2005; Giesen, 2013; Banjarbaru Forestry Research Unit, FORDA and Graham, 2014; Graham et al., 2017).

\section{Ecosystem Services Selection and Quantification}

The ecosystem services (ES) selected for this study were based on the Millennium Ecosystem Assessment, together with a list of beneficial functions of peatlands (Joosten and Clarke, 2002; FAO, 2014), ecosystem goods and services from plantation forests (Bauhus et al., 2010) and on valuation of ES (Hein et al., 2006). We selected four ES for this study: (1) carbon emission (climate regulation); (2) carbon sequestration (climate regulation); (3) provisioning (marketable commodities/food- and by-products); (4) biodiversity (habitat for species). For climate regulation, we focused only on carbon sequestration, and carbon emissions due to peat oxidation, which are described in literature as the most important aspects in the carbon balance of tropical peatland (Page et al., 2011).

The quantification of the four selected ES was done as follows: carbon emission due to peat oxidation was quantified as $\mathrm{C}-\mathrm{CO}_{2} \mathrm{ha}^{-1} \mathrm{yr}^{-1}$ (where $\mathrm{C}-\mathrm{CO}_{2}$ is the carbon content of $\left.\mathrm{CO}_{2}\right)^{2}$. This was based on subsidence studies, and total and heterotrophic respiration data of oil palm and acacia on drained peatland (DID and LAWOO, 1996; Hooijer et al., 2006; Othman et al., 2011; Comeau et al., 2013; Couwenberg 
and Hooijer, 2013; Dariah et al., 2014; Marwanto and Agus, 2014; Carlson et al., 2015).

Carbon sequestration was quantified as above ground biomass in $\mathrm{t} \mathrm{C} \mathrm{ha-1} \mathrm{yr}^{-1}$. Where information on carbon sequestration for certain crops or crop mixtures was missing, we used sequestration rates from similar crops or systems (Verwer et al., 2008; Khasanah et al., 2012; Kho and Jepsen, 2015; Sumarga et al., 2016; Hashim et al., 2017).

Provisioning ecosystem services is here defined as nutritional or monetary value crops that smallholders can derive from the peatland (e.g. marketable commodities, food and by-products). This was assessed using four criteria relating to commonly used aspects of value chain development: (1) level of income; (2) diversification of income; (3) regularity of yield; (4) steady market demand (Giesen, 2013; FAO, 2014; Giesen and Sari, 2018).

Biodiversity was assessed using four criteria, three of them relating to commonly used aspects of biodiversity (heterogeneity of the habitat, presence of indigenous species, presence of trees). In addition, we included rewetting as this enhances natural peat processes (including fauna) and reduces fire risks (Peh et al., 2006; Wichtmann and Joosten, 2007; Azhar et al., 2015; Schröder et al., 2015; Ghazali et al., 2016; Page and Hooijer, 2016; Asmah et al., 2017; Meijaard et al., 2018).

A ranking system was developed for the ecosystem service values in the four scenarios. For every unit of ecosystem service, an assessment in scores was assigned, ranking from low (1) to high (4) (Table 1). The ranking was based on expert knowledge by the authors, and based on similar ecosystem service assessment studies (Apostolova et al., 2018; Millennium Ecosystem Assessment, 2005; van der Meer and Ibie, 2009). The assessment of the ES provisioning, and biodiversity was based of the total sum of valuation of the criteria, where every criterion received a value of $0 ; 0.5$ or 1 .
Consequently, every ES could receive a maximum of four points, which results in a total potential maximum score of 16 points per scenario. This method therefore does not make a distinction in order of priority between the ES. The assessment scores for every scenario were summed up $\left(\sum n_{i}\right)$. An overall performance assessment of the scenarios was calculated as the percentage of the maximum possible sum: $\left(\sum \mathrm{n}_{\mathrm{i}} / \sum \mathrm{n}_{\mathrm{i}(\max )}\right){ }^{*} 100$.

where:

$\sum \mathrm{n}_{\mathrm{i}}$ - sum of parameter assessment (sum of 1-4 scores per ecosystem).

$\sum \mathrm{n}_{\mathrm{i}(\max )}$ - sum of the maximum of parameter assessment (i.e. $\mathrm{n}^{*} 4=16$ ).

PA - performance assessment, in percentage: $\left(\sum \mathrm{n}_{\mathrm{i}} / \sum \mathrm{n}_{\mathrm{i}(\max )}\right) * 100$.

\section{Interviews with Stakeholders Involved in the Oil Palm Industry}

In total, 50 stakeholders interviews were conducted, of which 37 were interviews with the owners of independent oil palm smallholders ${ }^{3}$ on peat and 13 interviews with specialists, including five researchers and specialists, five plantation managers and controllers, and three market sellers. Two different blueprint interview forms were used; one for the smallholders and one for the specialist interviews (Appendices 1 and 2 are available as supplementary materials). For the smallholders, the results of every question were presented as percentage of the answered questions, including the number of respondents for that particular question $(\mathrm{n}=\#)$. The qualitative interview data were categorised and merged when possible, based

${ }^{3}$ Smallholders are here defined as farmers having less than 50 ha of land, and grow oil palm in a monoculture or polyculture plantation (Azhar et al., 2015).

TABLE 1. METHODOLOGY OF ECOSYSTEM SERVICES ASSESSMENT OF SCENARIOS

\begin{tabular}{|c|c|c|c|c|c|c|}
\hline \multirow[b]{2}{*}{ Ecosystem service } & \multirow[b]{2}{*}{ Indicator/criterion } & \multirow[b]{2}{*}{ Quantification } & \multicolumn{4}{|c|}{ Assessment scale (scores) } \\
\hline & & & 1 & 2 & 3 & 4 \\
\hline Carbon emissions & $\begin{array}{l}\text { Carbon emission from } \\
\text { peat oxidation }\end{array}$ & t C-CO $\mathrm{ha}^{-1} \mathrm{yr}^{-1}$ & $>15$ & $10-15$ & $5-10$ & $<5$ \\
\hline Carbon sequestration & Above ground biomass & t C ha-1 $\mathrm{yr}^{-1}$ & $<2$ & $2-3.5$ & $3.5-5$ & $>5$ \\
\hline Provisioning & $\begin{array}{l}\text { 1) Monetary value } \\
\text { 2) }>1 \text { commodity } \\
\text { diversification of income } \\
\text { 3) Regular harvest } \\
\text { 4) Steady market }\end{array}$ & $\begin{array}{l}\text { Total of scores, } \\
0-1 \text { per criterion }\end{array}$ & $0-1$ & 2 & 3 & 4 \\
\hline Biodiversity & $\begin{array}{l}\text { 1) Polyculture } \\
\text { 2) Paludiculture } \\
\text { 3) Native } \\
\text { 4) Tree-based }\end{array}$ & $\begin{array}{l}\text { Total of scores, } \\
0-1 \text { per criterion }\end{array}$ & $0-1$ & 2 & 3 & 4 \\
\hline
\end{tabular}


on the essence of the answers and on keywords. Due to the limited number of interviews and the variability amongst the interviewees, the data of the specialist interviews were only analysed as additional comments and perceptions as personal communication.

\section{RESULTS AND DISCUSSION}

\section{Selection of Non-drainage Peatland Species}

We selected 32 species which could be used in alternative, non-drainage peatland systems (Table 2). This selection was based on the 82 priority species recognised by PROSEA ${ }^{4}$ and additional literature (Ambak and Melling, 2000; Salleh and van den Berg, 2005; Giesen, 2013; FAO, 2014; Graham et al., 2017). The FAO (2014) and Giesen (2013) described return of commodities on peat, Banjarbaru Forestry Research Unit, FORDA and Graham (2014) described known ecological tolerances and successional stages of a range PSF species, and Salleh and van den Berg (2005) provided a selection of NTFP species to be suitable for community cultivation. There is still a lack of information on species and some of these species might not have high tolerances for prolonged inundation/flooding (Banjarbaru Forestry Research Unit, FORDA and Graham 2014). One of the few studies investigating how water management regimes affect sustainability of crops grown on peat, was done by Wösten and Ritzema (2001). They indicate that with a peat depth of $200-250 \mathrm{~cm}$, oil palm can be grown for 20-30 years (water table 50 $\mathrm{cm}$ ), and sago for 40-60 years (water table $25 \mathrm{~cm}$ ).

\section{Ecosystem Service Assessment of the Four Scenarios}

The ecosystem service assessment illustrates the effect of the four scenarios on ES (Table 3). An overview of the results that were used for this ecosystem service assessment is shown in Appendix 3 in the supplementary material. Overall, scenario 4 scores the highest with $81 \%$ of the maximum performance value, followed by scenario $3(75 \%)$, scenario $2(69 \%)$ and scenario $1(38 \%)$. Scenario 4

\footnotetext{
4 Plant Resources of South-east Asia (PROSPEA) was a programme involving Forest Research Institute Malaysia (FRIM) (Malaysia), Lembaga Ilmu Pengetahuan Indonesia (LIPI) (Indonesia), Institute of Ecology and Biological ResearchNational Centre for Scientific Research (IEBR-NCSR) (Vietnam), University of Technology (UNITECH) (Papua New Guinea), The Philippine Council for Agriculture, Aquatic and Natural Resources (PCARRD) (The Philippines), Thailand Institute of Scientific and Technological Research (TISTR) (Thailand) and Wageningen Agricultural University, The Netherlands. PROSEA ran from 1990-2004 and resulted in a list of 5000+ useful plant species, arranged according to the various commodity groups.
}

is followed by scenario 3 with $75 \%$, and scenario 2 with $69 \%$. Scenario 1, the baseline scenario of oil palm contributes the lowest with $38 \%$ to all ES. The performance of every scenario differs per ES, which is more clearly illustrated in Figure 2. This figure shows that scenarios 1 and 2 score the highest on production of commodities, scenario 4 scores the highest on biodiversity, scenario 3 scores the highest on carbon sequestration and scenarios 3 and 4 score the highest on carbon emission. Although the assessment is conceptual and sensitive to many variables, the potential impact of different scenarios remains tangible.

\section{Perception of Stakeholders}

All smallholder respondents $(n=37)$ were satisfied with growing oil palm. People generally felt that oil palm is easy to take care of compared to other crops. Of 35 respondents, $67.6 \%$ had grown other crops before, $27.0 \%$ had not. Of the 32 species from the shortlist, only seven species were cultivated by $18.9 \%$ of the respondents (Table 4). None of the respondents considered cultivating any of the (other) species in the shortlist if it was possible. The most frequently mentioned reason was low and unsteady income. Thirty-four respondents elaborated on the environmental sustainability of the plantations, and $76.5 \%$ of the smallholders found this to be very important. Many smallholders believed that the conservation of peat is important, because a healthy soil leads to a healthy crop. Of the respondents, $20.6 \%$ were not sure about their perception on the environmental sustainability of their land, they often felt it is important, but they did not know about specific issues. Only 2.9\% of the respondents did not find the environmental sustainability of their land important. Of all smallholder respondents, $73.0 \%$ experienced soil compaction as well as soil subsidence, and $10.8 \%$ experienced compaction only. From the remaining respondents, $10.8 \%$ experienced no subsidence or compaction, and $5.4 \%$ did not know. Fourteen respondents mentioned what effect they experience from peat subsidence and / or compaction. Of these respondents, the most frequently mentioned effect with $28.6 \%$ was decreased soil quality, and the need for more or improved soil amendment (Table 5). Out of 25 respondents, only $9.1 \%$ of the smallholders would consider changing to a paludiculture system if they could maintain the same income and $45.5 \%$ of the respondents disagreed, while $45.5 \%$ would 'maybe consider it'. A change to other types of land use are quite costly and thus require substantial incentive from other parties (e.g. knowledge, physical help, machinery and technical assistance). Moreover, if farmers' revenue will not increase from the land use change, there is no reason for them to shift their agricultural system in the first place. Most 
TABLE 2. SHORTLIST OF SPECIES POTENTIALLY SUITABLE FOR PALUDICULTURE SCENARIOS

\begin{tabular}{|c|c|c|c|c|}
\hline$\#$ & Scientific name & Commonl names* & Family & Main use \\
\hline 1 & Aleurites moluccana & Candle nut (E), buah keras (M) & Euphorbiaceae & Nut \\
\hline 2 & Baccaurea motleyana & Common rambai $(\mathrm{E}), \operatorname{rambai}(\mathrm{M})$ & Euphorbiaceae & Fruit \\
\hline 3 & Baccaurea racemosa & Menteng, setambun $(\mathrm{M})$ & Euphorbiaceae & Fruit \\
\hline 4 & Chloranthus erectus & Keras tulang (M) & Chloranthaceae & Tea \\
\hline 5 & Dimocarpus longan & Longan (E), mata kucing (M) & Sapindaceae & Fruit \\
\hline 6 & Donax canniformis & Common donax, bemban (M) & Marantaceae & Weaving \\
\hline 7 & Dyera polyphylla & Swamp jelutong, jelutung (M) & Apocynaceae & Latex \\
\hline 8 & Elateriospemum tapos & Tapas (E, M) & Euphorbiaceae & Nut \\
\hline 9 & Finschia chloraxantha & Finschia nuts (E) & Proteaceae & Nut \\
\hline 10 & Flacourtia rukam & India plum (E), rukam (M) & Flacourtiaceae & Fruit \\
\hline 11 & Garcinia mangostana & Mangosteen (E), manggis (M) & Guttiferae & Fruit \\
\hline 12 & Garcinia morella & Indian gambodge tree $(\mathrm{E})$, asam gelugor $(\mathrm{M})$ & Guttiferae & Fruit \\
\hline 13 & Ipomoea aquatica & Water spinach (E), kangkung (M) & Convolvulaceae & Vegetable \\
\hline 14 & Mangifera caesia & Mango (E), binjai (M) & Anacardiaceae & Fruit \\
\hline 15 & Mangifera foetida & Horse mango (E), bacang, machang (M) & Anacardiaceae & Fruit \\
\hline 16 & Mangifera griffithii & Rawa, mangga keal (M) & Anacardiaceae & Fruit \\
\hline 17 & Melaleuca cajaputi & Gelam, pokok kaya putih (M), paperbark (E) & Essential oil & \\
\hline 18 & Metroxylon sagu & Sago palm (E), sagu (M) & Arecaceae & Starch \\
\hline 19 & Momordica charantia & $\begin{array}{l}\text { Bitter gourd, bitter melon, balsam-apple, } \\
\text { balsam-pear (E) }\end{array}$ & Cucurbitaceae & Vegetable \\
\hline 20 & Nephelium cuspidatum & Kedet, rambutan kabung $(\mathrm{M})$ & Sapindaceae & Fruit \\
\hline 21 & Nephilium lappaceum & Rambutan (E, M) & Sapindaceae & Fruit \\
\hline 22 & Nephelium maingayi & Buah raydun, ridan $(\mathrm{M})$ & Sapindaceae & Fruit \\
\hline 23 & Rhodomyrtus tomentosa & Rose myrtle (E), kemunting (M) & Myrtaceae & Fruit \\
\hline 24 & Shorea compressa & Tengkawang (I) & Dipterocarpaceae & Oil bearing illipe nuts \\
\hline 25 & Shorea macrophylla & $\begin{array}{l}\text { Tengkawang hantelok (I), meranti merah } \\
\quad \text { muda (M) }\end{array}$ & Dipterocarpaceae & Oil bearing illipe nuts \\
\hline 26 & Shorea pinanga & $\begin{array}{l}\text { Tengkawang rambai }(\mathrm{I}), \text { kawang pinang, } \\
\text { meranti langgai bukit }(\mathrm{M})\end{array}$ & Dipterocarpaceae & Oil bearing illipe nuts \\
\hline 27 & Shorea stenoptera & $\begin{array}{l}\text { Tengkawang tungkul (I), engkabang } \\
\text { kerangas, engkabang rusa }(\mathrm{M})\end{array}$ & Dipterocarpaceae & Oil bearing illipe nuts \\
\hline 28 & Shorea teysmanniana & Meranti bunga, meranti lilin, seraya bunga (M) & Dipterocarpaceae & Oil bearing illipe nuts \\
\hline 29 & Stenochlaena palustris & Pucuk paku, midin (M), pakis (I) & Blechnaceae & Vegetable \\
\hline 30 & Syzgium aqueum & Water apple (E), jambu air (M) & Myrtaceae & Fruit \\
\hline 31 & Vaccineum bracteatum & Sea bilberry $(\mathrm{E})$, kelempadang $(\mathrm{M})$, rangas $(\mathrm{I})$ & Ericaceae & Fruit \\
\hline 32 & Vatica mangachapoi & Resak julong, resak bajau $(\mathrm{M})$ & Dipterocarpaceae & Oil bearing illipe nuts \\
\hline
\end{tabular}

Note: *English (E), Malay (M), Indonesian (I).

Data from FAO (2014); Giesen (2013); Graham et al. (2017); Salleh and van der Berg (2005).

oil palm smallholders mentioned they rely heavily on the oil palm harvest for supporting their families and were hesitant to change to an unknown system. From the 25 respondents who elaborated on their opinion on paludiculture, $93.3 \%$ answered 'maybe' and $66.7 \%$ answered 'no', and $33.3 \%$ answered with 'yes' (Table 6). Most of the respondents that answered 'maybe, if there was more land area to try it out', were in their first or second year of their oil palm planting, and did not experience the high yields of oil palm yet. Most smallholders agreed that they would need a lot of help if an alternative system like paludiculture were to be implemented. This is recognised by Lim et al. (2012) who stated that smallholders would need more technical guidance and financial support to be able to implement better management practices for oil palm cultivation. The unfamiliarity of smallholders with a system like paludiculture, their educational level and their lack of awareness of environmental issues could have negatively influenced their opinion. However, the results illustrate the perceived negative perception of smallholders on these systems.

In the specialist interviews $(n=13)$ another set of questions was asked. When asked about the development of the oil palm industry on peat in the future, the main opinion of the plantation controllers ( $n=5)$ was quite optimistic. They did not foresee many problems in the future for oil palm plantations on peat, and were of the opinion that technical solutions would be able to solve future problems with draining or peat subsidence. Overall, the perception of specialists on the feasibility of alternative scenarios was negative. None of the 
TABLE 3. RESULT ASSESSMENT OF SCENARIOS ON CONTRIBUTION TO ECOSYSTEM SERVICES

\begin{tabular}{|c|c|c|c|c|c|c|}
\hline Ecosystem services & Scale/criteria & Scoring & Scenario 1 & Scenario 2 & Scenario 3 & Scenario 4 \\
\hline Carbon emission & $>15$ & 1 & 18 & - & - & - \\
\hline \multirow{3}{*}{$\left(\mathrm{t} C-\mathrm{CO}_{2} \mathrm{ha}^{-1} \mathrm{yr}^{-1}\right)$} & $10-15$ & 2 & - & 13 & - & - \\
\hline & $5-10$ & 3 & - & - & - & - \\
\hline & $<5$ & 4 & - & - & 3 & 3 \\
\hline \multicolumn{3}{|l|}{ Carbon emission score } & 1 & 2 & 4 & 4 \\
\hline Carbon sequestration & $<2$ & 1 & 1.4 & - & - & - \\
\hline \multirow[t]{3}{*}{$\left(\mathrm{tCha}{ }^{-1} \mathrm{yr}^{-1}\right)$} & $2-3,5$ & 2 & - & - & - & - \\
\hline & $3,5-5$ & 3 & - & 4.3 & - & 4.3 \\
\hline & $>5$ & 4 & - & - & 5.8 & - \\
\hline \multicolumn{3}{|l|}{ Carbon seq. score } & 1 & 3 & 4 & 3 \\
\hline \multirow[t]{4}{*}{ Provisioning } & $\begin{array}{l}\text { Level of income } \\
>1 \text { commodity }\end{array}$ & $0-1$ & 1 & 0.5 & 0.5 & 0.5 \\
\hline & diversification of income & $0-1$ & 0 & 1 & 0 & 1 \\
\hline & Regular harvest & $0-1$ & 1 & 1 & 0.5 & 0.5 \\
\hline & Steady market & $0-1$ & 1 & 0.5 & 0 & 0 \\
\hline \multicolumn{3}{|l|}{ Provisioning score } & 3 & 3 & 1 & 2 \\
\hline \multirow[t]{4}{*}{ Biodiversity } & Polyculture & $0-1$ & 0 & 1 & 0 & 1 \\
\hline & Paludiculture & $0-1$ & 0 & 1 & 1 & 1 \\
\hline & Native species & $0-1$ & 0 & 0.5 & 1 & 1 \\
\hline & Tree-based & $0-1$ & 0 & 0.5 & 1 & 1 \\
\hline \multicolumn{3}{|l|}{ Biodiversity score } & 1 & 3 & 3 & 4 \\
\hline \multicolumn{3}{|c|}{ Total Ecosystem Services scores $\left(\sum \mathrm{ni}\right)$} & 6 & 11 & 12 & 1 \\
\hline \multicolumn{3}{|c|}{ Performance Assessment (\%) } & 38 & 69 & 75 & 81 \\
\hline
\end{tabular}

Note: *Scenario 1 - baseline mono-oil palm; Scenario 2 - transition to poly-PAL; Scenario 3 - mono-paludiculture; Scenario 4 - poly-paludiculture.

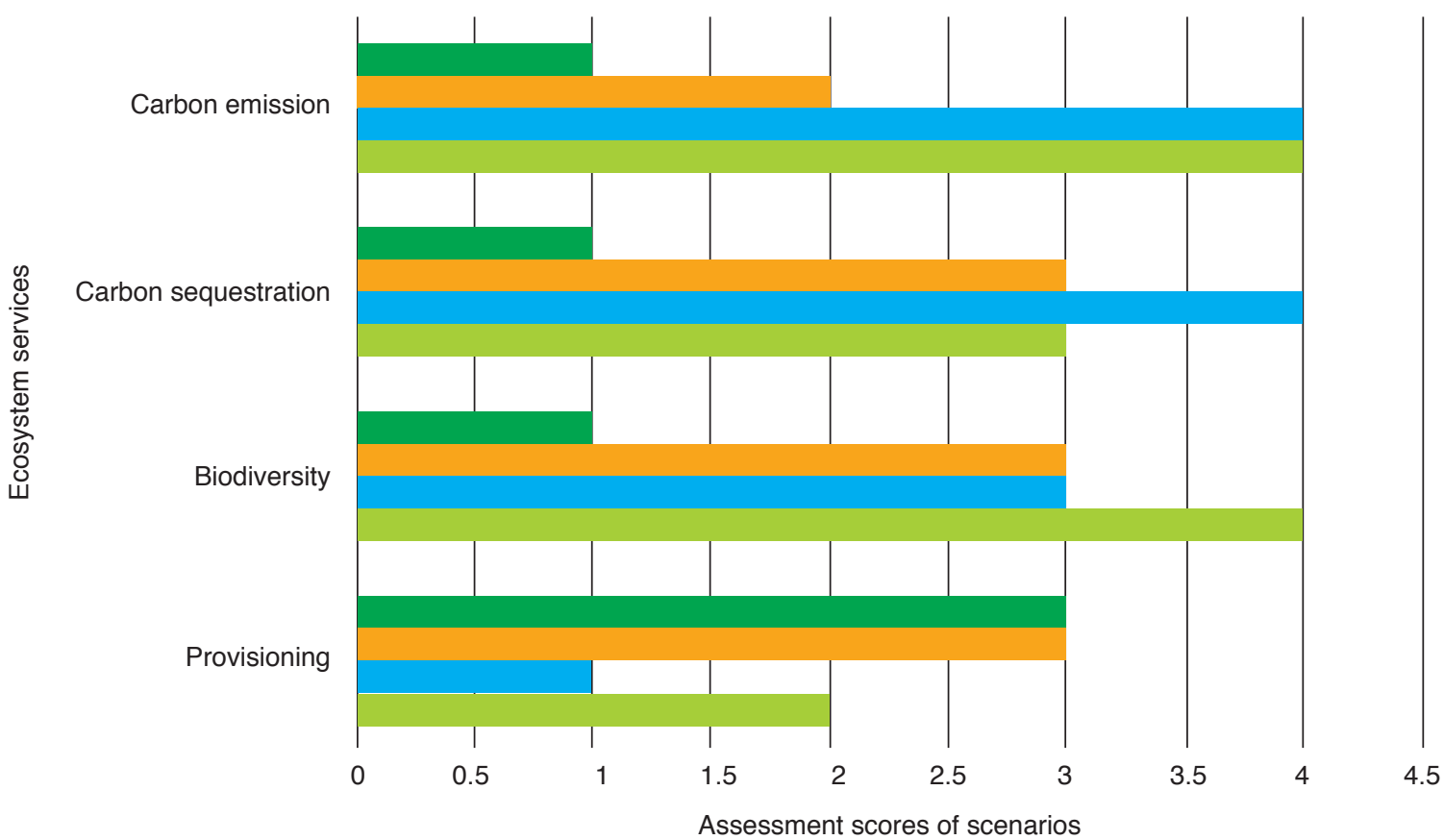

S1

S2

S3

S4

Figure 2. Assessment score of scenarios per ecosystem service (S1: baseline scenario; S2: transition to mixed paludiculture; S3: monoculture paludiculture; S4: mixed paludiculture). 
TABLE 4. SMALLHOLDERS' MENTIONED SPECIES FROM SHORTLIST THAT THEY CULTIVATE

\begin{tabular}{ll}
\hline Species & $\#^{*}$ \\
\hline Nephelium lappaceu (rambutan) & 9 \\
Ipomea aquatica (kankung) & 4 \\
Dimocarpus longan (longan) & 3 \\
Syzgium aqueum (water apple) & 2 \\
Garcinia mangostana (mangosteen) & 2 \\
Chloranthus erectus (keras tulang) & 1 \\
Dyera polyphylla (jelutung) & 1 \\
\hline Note: *Indicates how often the specific species was mentioned
\end{tabular}

Note: *Indicates how often the specific species was mentioned $(\mathrm{n}=37)$.

TABLE 5. RESPONDENTS' EXPERIENCED EFFECT FROM PEAT SUBSIDENCE AND COMPACTION

\begin{tabular}{lc}
\hline Experienced effect & Frequency (\%) \\
\hline Decreased soil quality, needs more & \\
$\quad$ soil amendment & 28.6 \\
Increased flooding & 21.4 \\
Increased leaning & 14.3 \\
The soil is easier to walk and work & \\
$\quad$ on now the soil is compacter & 14.3 \\
Planting is more difficult & 7.1 \\
Compaction is caused by root system & \\
$\quad$ of oil palm & 7.1 \\
Soil erosion & 7.1 \\
Not good for plants & 7.1 \\
\hline
\end{tabular}

Note: ${ }^{*} \mathrm{n}=14$, multi-response. paludiculture systems could be more feasible for smallholders since they do not use heavy machinery. It was also suggested that the double avenue system (for intercropping) is not yet practical for big estates. Moreover, it was indicated that utilising indigenous paludiculture crops would be difficult due to the problems with the propagation of some selected species.

\section{CONCLUSION AND RECOMMENDATION}

Overall, it can be concluded that alternative paludiculture systems are likely to contribute more to ES than oil palm, and the intention for sustainable use of peatland is presented. Although many smallholders recognise the issues with peat subsidence and compaction, replacing oil palm with alternative systems like paludiculture in Malaysia is not yet realistic. The most important impediments are a lack of knowledge on potential of non-drainage peatland species and its associated value chains, as well as the technical difficulty for smallholders to implement such a system.

It is recommended to further investigate the issues associated to oil palm growing on undrainable

TABLE 6. OPINION OF RESPONDENTS ON CHANGING THEIR SYSTEM TO A PALUDICULTURE SYSTEM, INCLUDING RESPONDING REASONS FOR THEIR OPINION

\begin{tabular}{llr}
\hline $\begin{array}{l}\text { Opinion on } \\
\text { paludiculture }\end{array}$ & \multicolumn{1}{c}{ Reasons } & $\#^{*}$ \\
\hline No & Oil palm is too economically important for their livelihood & 7 \\
& Hard to change the whole land system & 7 \\
& No faith in subsidy system & 7 \\
& Too much effort/workers needed & 2 \\
& Soil conditions not suitable for other species & 2 \\
& Not enough area to try out & 1 \\
& No species as lucrative as oil palm. Other species do not produce higher revenues & 1 \\
& Too costly to change to another system & 1 \\
& Peat won't restore anymore & 1 \\
Maybe & Only if there was more land area to try it out & 12 \\
& Only if the alternative species provide better revenues, otherwise no point in trying out & 2 \\
Yes & But not enough land to try it out & 1 \\
\hline Note: ${ }^{*}$ Indicates how often the specific reason was mentioned (n-25, multi-response).
\end{tabular}

Note: * Indicates how often the specific reason was mentioned ( $n=25$, multi-response).

respondents had heard of paludiculture, or the name or the management system itself. Moreover, none of the respondents believed there is a crop as lucrative as oil palm and they were sceptical about the feasibility of management practices on wet peat soils. However, in addition to the questions, three respondents mentioned that they believed that if a system like paludiculture could work, it could be of great importance. It was suggested that peat areas. It is advised to collaborate with specialists and conduct more research on the potential of non-drainage peatland species in paludiculture systems and to further evaluate the effects on a wider range of ecosystem services. Moreover, we advise to conduct an economic analysis of ES of the different scenarios. We also suggest setting up trial studies with suitable alternative species to gain more insight in crop uses, planting regimes, life 
cycle, intercropping possibilities, yield, harvesting methods, and value chains. Based on the outcomes of these trials, we suggest to test the most promising species within the scenario which have the highest score for the ecosystem services assessment, i.e. scenario four: 'immediate change to a polyculture paludiculture system'. In addition, it is important to acquire more data on the selected and additional ecosystem services, to verify our findings and get a more complete ecosystem service assessment for all scenarios.

\section{SUPPLEMENTARY INFORMATION}

The supplementary materials on smallholder interview form (Appendix 1); specialist interview form (Appendix 2) and results used for the ecosystem service assessment (Appendix 3) can be found via http://jopr.mpob.gov.my/wp-content/ uploads / 2019 / 08/jopr 2019-joline-appendix.pdf

\section{ACKNOWLEDGEMENT}

We thank MPOB and Sarawak Oil Palms Berhad for their support. We are grateful to Shariffah Nur Atikah, Aqilah Oon and Ivan Yaman for supporting Joline Middelberg during her field surveys. We want to thank the local communities and smallholders for their kindness, generosity, and willingness to participate in this research. We also thank three anonymous reviewers for their valuable comments.

This work is greatly based on research done by Joline Middelberg for her thesis (Forest and Nature Management, Van Hall Larenstein University of Applied Sciences). It was partly funded under the bi-lateral collaboration between The Netherlands and Malaysia on Sustainable Oil Palm (SOP) project (BO-20-007-451).

\section{REFERENCES}

Ambak, K and Melling, L (2000). Management practices for sustainable cultivation of crop plants on tropical peatland. Proc. of the International Symposium on Tropical Peatlands. Bogor, Indonesia, 22-23 November 1999. p. 119-134.

Apostolava, I; Sopotlieva, D; Velev, N; Vassilev, V; Bratanova-Doncheva, S; Gocheva, K and Chipev, N (2018). Methodology for Assessment and Mapping of Grassland Ecosystems Condition and their Services in Bulgaria. Part B3. 2 pp.

Asmah, S; Ghazali, A; Syafiq, M; Yahya, M S; Peng, T L; Norhisham, A R; Chong, L P; Azhar, B and
Lindenmayer, D B (2017). Effects of polyculture and monoculture farming in oil palm smallholdings on tropical fruit-feeding butterfly diversity. Agricultural and Forest Entomology, 19(1): 70-80. DOI: 10.1111/ afe.12182.

Azhar, B; Saadun, N; Puan, C L; Kamarudin, N; Aziz, N; Nurhidayu, S and Fischer, J (2015). Promoting landscape heterogeneity to improve the biodiversity benefits of certified palm oil production: Evidence from Peninsular Malaysia. Global Ecology and Conservation. Elsevier B.V., 3. p. 553-561. DOI: 10.1016/j.gecco.2015.02.009.

Banjarbaru Forestry Research Unit, FORDA and Graham, L L B (2014). Tropical Peat Swamp Forest Silviculture in Central Kalimantan. A Series of Five Research Papers. 95 pp.

Bauhus, J; Van Der Meer, P and Kaninnen, M (2010). Ecosystem Goods and Services from Plantation Forests. London \& Washington, DC: Earthscan. 25 pp. DOI: $10.1080 / 01431161003777205$.

Carlson, K M and Garret, R D (2018). Environmental Impacts of Tropical Soybean and Palm Oil Crops. Oxford Research Encyclopedia of Environmental Science. 48 pp. DOI: 10.1093/ acrefore/9780199389414.013.234.

Carlson, K M; Goodman, L K and May-Tobin, C C (2015). Modeling relationships between water table depth and peat soil carbon loss in Southeast Asian plantations. Environmental Research Letters, 10(7): 074006. DOI: 10.1088/1748-9326/10/7/074006.

Comeau, L P; Hergoualc'h, K; Smith, J U and Verschot, L (2013). Conversion of Intact Peat Swamp Forest to Oil Palm Plantation. Effects on Soil $\mathrm{CO}_{2}$ Fluxes in Jambi, Sumatra. CIFOR Working Paper No. 110. 18 pp.

Couwenberg, J and Hooijer, A (2013). Towards robust subsidence-based soil carbon emission factors for peat soils in South-east Asia, with special reference to oil palm plantations. Mires \& Peat, 12: 1-13. http:/ / pixelrauschen.de/wbmp/media/ map12/map_12_01.pdf

Dariah, A; Marwanto, S and Agus, F (2014). Rootand peat-based $\mathrm{CO}_{2}$ emissions from oil palm plantations. Mitigation and Adaptation Strategies for Global Change, 19: 831-43.

DID (2001). Water Management Guidelines for Agricultural Development in Lowland Peat Swamps of Sarawak. Kuching: Sarawak Department of Irrigation and Drainage.

DID and LAWOO (1996). Western Johore Integrated Agricultural Development Project, Peat Soil Management Study. 
EPOA (2016). The Palm Oil Story. Facts and Figures. Zoetermeer, The Netherlands. https:// www.palmoilandfood.eu/sites / default / files / EuropeanPalmOilAlliance-Factsheet2014-DEF.pdf. $18 \mathrm{pp}$.

FAO (2014). Towards climate-responsible peatlands management. Mitigation of Climate Change in Agriculture, Series 9 (Biancalani, R and Avagyan, A eds.). Rome: FAO. http: / / www.fao.org/3/a-i4029e. pdf. 117 pp.

Fitzherbert, E B; Struebig, M J; Morel, A; Danielsen, F; Brühl, C A; Donald, P F and Phalan, B (2008). How will oil palm expansion affect biodiversity? Trends in Ecology and Evolution, 23(10): 538-545. DOI: $10.1016 /$ j.tree.2008.06.012.

Ghazali, A; Asmah, S; Syafiq, M; Yahya, M S; Aziz, N; Peng, L P; Norhisham, A R; Puan, C L; Turner, E C and Azhar, B (2016). Effects of monoculture and polyculture farming in oil palm smallholdings on terrestrial arthropod diversity. J. Asia-Pacific Entomology, 19(2): 415-421. DOI: 10.1016/j. aspen.2016.04.016.

Giesen, W (2013). Paludiculture: Sustainable Alternatives on Degraded Peat Land in Indonesia. QANS Activity 3.3: Quick Assessment and Nationwide Screening of Peat and Lowland Resources and Action Planning for the Implementation of a National Lowland Strategy. Euroconsult Mott MacDonald, for the Netherlands Partners for Water Programme (PVW3A10002), BAPPENAS and the Ministry of Public Works. 83 pp. DOI: 10.13140/RG.2.2.15539.73760.

Giesen, W (2015). Utilising non-timber forest products to conserve Indonesia's peat swamp forests and reduce carbon emissions. J. Indonesian Natural History, 3(2): 69-72.

Giesen, W and Sari, E N N (2018). Tropical Peatland Restoration Report: The Indonesian Case. Berbak Green Prosperity Partnership/Kemitraan Kesejatheraan Hijau (Kehijau Berbak). 99 pp. DOI: 10.13140/ RG.2.2.30049.40808.

Graham, L L B; Giesen, W and Page, S E (2017). A common-sense approach to tropical peat swamp forest restoration in Southeast Asia. Restoration Ecology, 25(2): 312-321. DOI: 10.1111/rec.12465.

Hashim, Z; Subramaniam, V; Harun, M H and Kamarudin, N (2017). Carbon footprint of oil palm planted on peat in Malaysia. International J. Life Cycle Assessment, 6: 1-17. DOI: 10.1007/s11367-017-1367-y.

Hein, L; Van Koppen, K; De Groot, R S and Van Ierland, E C (2006). Spatial scales, stakeholders and the valuation of ecosystem services. Ecological Economics, 57(2): 209-228. DOI: $10.1016 / \mathrm{j}$. ecolecon.2005.04.005.

Hooijher, A; Silvius, M; Wösten, $\mathrm{H}$ and Page, S (2006). PEAT- $\mathrm{CO}_{2}$, Assessment of $\mathrm{CO}_{2}$ emissions from drained peatlands in SE Asia. Delft Hydraulics Report Q3943 (2006). p. 36.

Hooijer, A; Page, S; Canadell, J G; Silvius, M; Kwadijk, J; Wosten, $\mathrm{H}$ and Jauhiainen, J (2010). Current and future $\mathrm{CO}_{2}$ emissions from drained peatlands in Southeast Asia. Biogeosciences, 7(5): 1505-1514. DOI: 10.5194/bg-7-1505-2010.

Hooijer, A; Vernimmen, R; Visser, M and Mawdsley, $N$ (2015). Flooding projections from elevation and subsidence models for oil palm plantations in the Rajang Delta peatlands, Sarawak, Malaysia. Deltares Report 1207384.57 pp.

Ishikura, K; Hirano, T; Okimoto, Y; Hirata, R.; Kiew, F; Melling, L; Aeries, E B; Lo, K S; Musin, K K; Waili, J W; Wong, G X and Ishii, Y (2018). Soil carbon dioxide emissions due to oxidative peat decomposition in an oil palm plantation on tropical peat. Agriculture, Ecosystems and Environment. p. 202212. DOI: 0.1016/j.agee.2017.11.025.

Ismail, S; Khasim, N and Omar, R Z R (2009). Double-row avenue system for crop integration with oil palm. MPOB Information Series No. 424: 4 pp.

Joosten, H and Clarke, D (2002). Wise Use of Mires and Peatlands - Background and Principles Including a Framework for Decision-making. Saarijärvi, Finland: International Mire Conservation Group and International Peat Society. 304 pp.

Khasanah, N M; Van Noordwijk, M; Ekadinata, A; Dewi, S; Rahayu, S; Ningsih, H; Setiawan, A A; Dwiyanti, E and Octaviani, R (2012). The Carbon Footprint of Indonesian Palm Oil Production. Technical Brief No. 25: Palm Oil Series. Bogor, Indonesia. 26 pp.

Kho, L K and Jepsen, M R (2015). Carbon stock of oil palm plantations and tropical forests in Malaysia: A review. Singapore J. Tropical Geography, 36(2): 249266. DOI: $10.1111 /$ sjtg. 12100 .

Kushairi, A; Loh, S K; Azman, I; Hishamuddin, E; Ong-Abdullah, M; Izuddin, Z B M N; Razmah, G; Sundram, S and Parveez, G K A (2018). Oil palm economic performance in Malaysia and R \& D progress in 2017. J. Oil Palm Res. Vol. 30(2): 163-195. DOI: 10.21894/jopr.2018.0030.

Kushairi, A; Singh, R and Ong-Abdullah, M (2017). The oil palm industry in Malaysia: Thriving with 
transformative technologies. J. Oil Palm Res. Vol. 29(4): 431-439.

Lampela, M; Jauhiainen, J; Sarkkola, S and Vasander, H (2017). Promising native tree species for reforestation of degraded tropical peatlands. Forest Ecology and Management. Elsevier B.V., 394. p. 52-63. DOI: 10.1016/j.foreco.2016.12.004.

Lim, K H; Lim, S S; Parish, F and Suharto, R (2012). RSPO Manual on Best Management Practices (BMPs) for Existing Oil Palm Cultivation on Peat. Kuala Lumpur, Malaysia. 111 pp.

Manap, N; Sidharta, M and Parera, A (2009). Commodity chain assessment: Case of candlenut in transboundary Timor and Indonesia. J. NTT Studies, 1(2): 147-158.

Marwanto, $\mathrm{S}$ and Agus, $\mathrm{F}$ (2014). Is $\mathrm{CO}_{2}$ flux from oil palm plantations on peatland controlled by soil moisture and/or soil and air temperatures? Mitigation and Adaptation Strategies for Global Change, 19(6): 809-819.

Meijaard, E; Garcia-Ulloa, J; Sheil, D; Wich, S A; Carlson, K M; Juffe-Bignoli, D and Brooks, T M (2018). Oil Palm and Biodiversity: A Situation Analysis by the IUCN Oil Palm Task Force. IUCN Oil Palm Task Force Gland, Switzerland. DOI: 10.2305/IUCN. CH.2018.11.en. 116 pp.

Miettinen, J; Shi, C and Liew, S C (2016). Land cover distribution in the peatlands of Peninsular Malaysia, Sumatra and Borneo in 2015 with changes since 1990. Global Ecology and Conservation. Elsevier B.V., p. 67-78. DOI: $10.1016 /$ j.gecco.2016.02.004.

Millenium Ecosystem Assessment (2005). Ecosystems and Human Well-being: Wetlands and Water Synthesis. Washington, DC: Island Press. 68 pp.

MPOB (2017). Oil palm planted area 2017. http:/ / bepi.mpob.gov.my/index.php/en/statistics / area / 188-area-2017/ 856-oil-palm-planted-area-asat-dec-2017.html.

MPS (2016). Peatlands in harmony - Agriculture, industry and nature. Poster presentations at the $15^{\text {th }}$ International Peat Congress.

OAF (2014). Smallholder Agroforestry. Phase 4 Trial Report. 17 pp.

Omar, W; Aziz, N A; Mohammed, A T; Harun, M H and Din, A K (2010). Mapping of oil palm cultivation on peatland in Malaysia. MPOB Information Series No. 473: 4 pp.
Othman, H; Mohammed, A T; Darus, F M; Harun, M H and Zambri, M P (2011). Best management practices for oil palm cultivation on peat: Ground water-table maintenance in relation to peat subsidence and estimation of $\mathrm{CO}_{2}$ emissions at Sessang, Sarawak. J. Oil Palm Res. Vol. 23: 1078-1086.

Page, S E; Morrison, R; Malins, C; Hooijer, A; Rieley, J O and Jauhiainen, J (2011). Review of Peat Surface Greenhouse Gas Emissions from Oil Palm Plantations in Southeast Asia. White Paper No. 15. 80 pp. https:// www.theicct.org

Page, S E and Hooijer, A (2016). In the line of fire: The peatlands of Southeast Asia. Philosophical Transactions of the Royal Society B: Biological Sciences, 371(1696): 20150176. DOI: 10.1098/ rstb.2015.0176.

Peh, K S H; Sodhi, N S; De Jong, J; Sekercioglu, C H; Yap, C A M and Lim, S L H (2006). Conservation value of degraded habitats for forest birds in southern Peninsular Malaysia. Diversity and Distributions, 12(5): 572-581. DOI: $10.1111 / j .1366-$ 9516.2006.00257.x.

Posa, M R C; Wijedasa, L S and Corlett, R T (2011). Biodiversity and conservation of tropical peat swamp forests. BioScience, 61(1): 49-57. DOI: 10.1525/bio.2011.61.1.10.

RSPO (2018). RSPO Principles and Criteria for the Production of Sustainable Palm Oil. 12 pp.

Salleh, M N and Van Den Berg, J (2005). Constraints and opportunities of non-timber forest products (NTFPs) activities among the Iban communities living adjacent to the Maludam National Park, Sarawak. Joint Working Group Malaysia-The Netherlands: Sustainable Management of Peat Swamp Forests of Sarawak with Special Reference to Ramin. Alterra, Wageningen, Forest Department Sarawak, Malaysia. p. 625-689.

Schröder, C; Dahms, T; Paulitz, J; Wichtmann, $\mathrm{W}$ and Wichmann, S (2015). Towards large-scale paludiculture: Addressing the challenges of biomass harvesting in wet and rewetted peatlands. Mires and Peat, 16(13): 1-18.

SIIA (2017). Special Report Peatland Management $\mathcal{E}$ Rehabilitation in Southeast Asia: Moving from Conflict to Collaboration. $20 \mathrm{pp}$.

Sofiyuddin, M (2012). Assessment of profitability of land use systems in Tanjung Jabung Barat District, Jambi Province, Indonesia. Open J. Forestry, 02(04): 252-256. DOI: 10.4236/ ojf.2012.24031.

Sumarga, E; Hein, L; Hooijer, A and Vernimmen, R (2016). Hydrological and economic effects of oil 
palm cultivation in Indonesian peatlands. Ecology and Society, 21(2): 52.

Van Der Meer, P J and Ibie, B F (2009). Forestry and the EMRP. Project Report for Master Plan for the Conservation and Development of the Ex-mega Rice Project Area in Central Kalimantan. Euroconsult Mott MacDonald. 104 pp.

Verwer, C C; Van Der Meer, P J and Nabuurs, G J (2008). Review of Carbon Flux Estimates and Other Greenhouse Gas Emissions from Oil Palm Cultivation on Tropical Peatlands - Identifying the Gaps in Knowledge. Alterra Report 1731. Wageningen, The Netherlands. $46 \mathrm{pp}$.

Wichtmann, W and Joosten, H (2007). Paludiculture: Peat formation and renewable resources from rewetted peatlands. IMCG Newsletter, 2007/2. p. 24-28.
Wichtmann, W; Schröder, C and Joosten, H (2016). Paludiculture - Productive Use of Wet Peatlands. Stutgart, Germany: Schweizerbart'sche Verslagsbuchhandlung. $272 \mathrm{pp}$.

Widayati, A; Van Noordwijk, M and Tata, H L (2016). Agroforestry on Peatlands: Combining Productive and Protective Functions as Part of Restoration. 12 pp.

World Growth (2011). The Economic Benefit of Palm Oil to Indonesia. A Report by World Growth February 2011, World Growth Palm Oil Green Development Campaign. http://worldgrowth.org/site/wpcontent/uploads/2012/06/WG_Indonesian_Palm_ Oil_Benefits_Report-2_11.pdf

Wösten, H and Ritzema, H (2001). Land and water management options for peatland development in Sarawak, Malaysia. International Peat J., 11: 59-66. 